\title{
REFORM TO ABOLISH : A PRAGMATIC ANALYSIS OF PRISON LABOR \& STRIP SEARCHES IN QUEBEC CORRECTIONAL LAW
}

Alexis Marcoux Rouleau

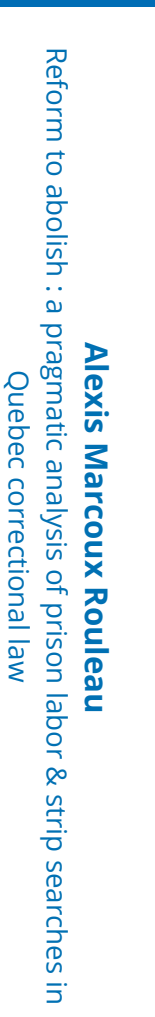




\section{Résumé}

Dans la dernière année, des thèmes abolitionnistes ont été au cœur de mobilisations comme \#BlackLivesMatter, \#MoiAussi, et \#LibérezLesTous. Cet article s'inspire d'une méthodologie sociolégale et féministe pour proposer une analyse pragmatique et abolitionniste de la Loi sur le système correctionnel du Québec (LSCQ). Je présente deux enjeux reflétant des torts structurels perpétués dans les prisons pour femmes le travail et les fouilles à nu - et soutiens que ces pratiques instillent des torts corporels quotidiens vu leur cadrage au sein de la LSCQ. Bien que le travail en prison soit présenté comme moyen de réinsertion sociale, vu la LSCQ les femmes reçoivent des salaires inadéquats relatifs au coût de vie en prison, ce qui limite l'accès aux produits menstruels et peut mener à des alternatives dangereuses. Pour ce qui est des fouilles à nu, celles-ci sont présentées comme favorisant la sécurité de l'institution mais sont subies comme agressions sexuelles infligées par l'état. La LSCQ prévoit que ces fouilles puissent être conduites dans une variété de circonstances à la discrétion des agents correctionnels, laissant ainsi place à une application discriminatoire des règlements et exposant les femmes racisées à davantage de violences en détention. Je conclus en présentant des réformes abolitionnistes qui pourront réduire ces torts corporels quotidiens à court terme. J'appelle aussi à une solidarisation avec les personnes incarcérées au sein des mouvements sociaux. 


\section{Abstract}

In the past year, abolitionist themes have been at the forefront of mobilizations such as \#BlackLivesMatter, \#MeToo, and \#FreeThemAll. This paper relies on socio-legal feminist methodology and proposes a pragmatic abolitionist analysis of correctional law, the Loi sur le système correctionnel du Québec (LSCQ). I emphasize two issues reflective of ongoing structural harms within women's jails - prison labor and strip searches - and argue that both practices instill everyday bodily harms due to their framing in the LSCQ. Although prison labor is presented as favoring social reinsertion, per the LSCQ incarcerated women receive inadequate wages relative to the cost of living in prison thus limiting their access to menstrual products and potentially leading to dangerous alternatives. As for strip searches, they are presented as means to ensure the safety of the institution yet are experienced as unsafe and as stateinflicted sexual assault. Per the LSCQ, strip searches can be conducted in a range of circumstances leaving much to correctional officers' discretion, thus allowing for discriminatory rule enforcement and exposing incarcerated women of color to further violence. I conclude by presenting short-term abolitionist reforms which could reduce these everyday bodily harms. I also call for increased solidarity with incarcerated people within social mobilizing and organizing. 


\section{INTRODUCTION}

[1] In the past year there have been worldwide mobilizations around \#BlackLivesMatter and defunding the police, \#FreeThemAll to decarcerate considering the pandemic, and another \#MeToo wave in the province of Québec. Although they appear separate, all three mobilizations speak to deep dissatisfaction with the current justice system at all levels: policing, courts, and incarceration. These mobilizations thus reflect abolitionist themes.

[2] The social wrongs decried over the past year also overlap: systemic racism and sexual violence are relevant to understanding incarceration processes and experiences in Canada. Disproportionate incarceration rates of Black, Indigenous, and Latinx people show that punishment is far from colorblind (Maynard 2017). Indeed, countries with higher rates of ethnic-based exclusion from power and with longer colonial regimes have higher rates of incarceration ( $n=134$, A. P. Davis and Gibson-Light 2020). A historical analysis also revealed that incarcerating Indigenous people emerged and prevails as a legal and normalized means of perpetuating colonial logics: dispossession, assimilation, and segregation (Chartrand 2019). Although incarcerated women have consistently been erased from \#MeToo mobilizations, the majority have experienced sexual violence (Hutchison 2020) and "almost all incarcerated Indigenous women have a history of sexual abuse" (National Inquiry into Missing and Murdered Indigenous Women and Girls 2019, 637).

[3] In this paper I propose an abolitionist analysis of correctional law in Quebec, the Loi sur le système correctionnel du Québec (hereafter LSCQ, 2002). After proposing an abolitionist framework, I emphasize two issues indicative of systemic racism and sexual violences within this setting: relying on existing critiques, I frame prison labor and strip searches as engendering bodily harms tied to social and historical structures. Using feminist socio-legal methods, I then describe correctional law and analyze its everyday bodily implications for women, especially poor, Black, and Indigenous women. I argue that due to their framing in correctional law, both practices instill daily harms upon women's bodies by impacting cost and quality of life in prison as well as creating space for discretion and discrimination. I conclude by proposing abolitionist reforms aiming to 
attenuate these harms in the here and now and encourage social movements to account for and create alliances with incarcerated people.

[4] This paper centers implications of correctional law for women, especially Indigenous and Black women. Indeed incarcerated women have consistently been treated as a "correctional afterthought" due to their small demographic weight, despite being the fastest-growing prison population worldwide for decades (Ross and Fabiano 1986, title; Walmsley 2015; Sudbury 2014). In Canada, 97\% of incarcerated women are held within provincial jails yet most research focuses on the $3 \%$ who are held in the federal system (Gartner, Webster, and Doob 2009). I thus focus on provincially incarcerated women, who are the afterthought to the afterthought. At 10.1\%, women indeed represent a small minority of the population in Quebec jails (Chéné and Chouinard 2018). Among these women, one in ten is Indigenous, a proportion which has tripled in less than a decade (9.8\% compared to 3.7\%, Chéné and Chouinard 2018). Indigenous women are incarcerated at five times their demographic weight (9.8\% in jail compared to $1.8 \%$ in Quebec) which is twice as much as Indigenous men (4.9\% in jail). Inuit women represent $58.2 \%$ of detained Indigenous women, or $5.7 \%$ of all women detained in Quebec jails (Chéné and Chouinard 2018). Thus the overincarceration of Indigenous women, as observed in Canadian penitentiaries (Chartrand 2019; Hutchison 2019) also holds true in Quebec jails. Although official statistics do not further distinguish women based on race or ethnicity,

[5] Further, women's jails in Quebec are a prime site for an abolitionist analysis as these have warranted much outcry in the past years around living conditions and human rights violations. In February 2016, one of two jails for women closed because it was outdated. Women were transferred to a mixed facility which the federal government had declared antiquated in 2012. Women were often confined in order to avoid men: women's and human rights organizations, incarcerated women, activists, and scholars thus formed the Coalition d'action et de surveillance de l'incarcération des femmes au Québec (hereafter CASIFQ) to call for an end to this practice and were joined by the provincial ombudsman (Protecteur du citoyen 2017). Mixed detention ended after 15 months. The CASIFQ continues to mobilize against women's detention conditions at this jail, condemning the lack of adaptation to women's needs; disrespectful correctional agents; repressive architecture; unsanitary conditions because of sewage backflow, pest, and insect infestations; problematic 
access to drinking water, heating, and healthcare; as well as abusive body searches (Ligue des droits et libertés 2021). Assisted by the CASIFQ, Gisèle Lafrance and Véronique De Levo (2019) submitted a temporary injunction request against this jail, arguing that detention conditions are inhumane and constitute cruel and unusual punishment. The Superior Court of Quebec rejected the temporary injunction request, considering these important and urgent questions should be addressed with a permanent injunction (Ligue des droits et libertés 2019). This jail remains in use despite five years of mobilisations by the CASIFQ and denounciations by the provincial ombudsman (Ligue des droits et libertés 2021; Protecteur du citoyen 2019 ; 2017).

\section{ABOLITION \& REFORM}

[6] This paper relies on an abolitionist framework to analyze prison labor and strip searches and to propose tangible ways to minimize harms caused by these practices. Abolitionism is theory and praxis aiming to eliminate oppressive institutions and to rethink responsibility, support, and safety through a focus on building community; historically, this has included abolishing slavery and the death penalty, while current efforts target policing, prison, border control, psychiatric institutions, and more (No Prisons n.d.; Mathiesen 2014; A. Y. Davis 2003 ; Russell and Carlton 2013). Abolitionism recognizes the past and present interplay of social structures such as racism, global capitalism, colonialism, and sexism, which are deployed to justify criminalizing and incarcerating those who are deemed expendable. Prisons are understood as current manifestations of colonialism and as extensions of racist systems such as slavery, lynching, segregation, and convict leasing (A. Y. Davis 2003 ; Chartrand 2019). Importantly, this "racism is always gendered, and imprisonment practices that are conventionally considered to be 'neutral' - such as sentencing, punishment regimes, and health care - differ in relation to the ways race, gender, and sexuality intersect" (A. Y. Davis and Shaylor 2001, 5 ; Sudbury 2009; Russell and Carlton 2013). All in all, "the prison functions ideologically as an abstract site into which undesirables are deposited, relieving us of the responsibility of thinking about the real issues afflicting those communities from which prisoners are drawn in such disproportionate numbers" (A. Y. Davis 2003, 16). 
[7] Despite its relatively recent invention, prison is seen as such an inevitable and permanent fixture of modern societies that its abolition is portrayed as idealistic (A. Y. Davis 2003). Abolitionists flip this critique: cycles of reform have been deployed since prison's inception yet have all too often resulted in expanding and consolidating punitive responses to social problems rather than making the institution more humane (A. Y. Davis 2003 ; Mathiesen 2014; Russell and Carlton 2013). Abolitionists thus distinguish between reformist reforms which "further consolidate and expand the system" and abolitionist reforms which "effect transformative change" by reducing reliance on punitive practices (Russell and Carlton 2013, 476 ; Mathiesen 2014; Sudbury 2009). Abolitionists indeed maintain an overarching goal of eliminating prison and structures like racism, colonialism, and global capitalism, while pragmatically pushing short-term reforms which undermine prison's foundations and limit the everyday harms inflicted upon incarcerated people (Sudbury 2009).

[8] Abolitionists and others have formulated critiques as to prison labor and strip searches, which are presented hereafter.

\section{CRITICAL PERSPECTIVES ON PRISON LABOR}

[9] In the 19th century, prison labor was framed as an opportunity for penance, reform, and rehabilitation, in a more humane way than corporal punishment of old (Hannah-Moffat 2001). Modern justifications for prison labor emphasize its potential for increased employability and social reinsertion (Marcoux Rouleau 2020). Critical and abolitionist scholars have contested these official narratives, linking prison labor to racial and gendered oppression.

[10] A historical and structural perspective helps understand prison labor as exploitation of Black and other incarcerated people of color as this institution operates on a "transformation of imprisoned bodies - and they are in their majority bodies of color - into sources of profit" (Browne 2007; Buck 2004; Goodwin 2019 ; Halladay 2018; Thompson 2012 ; A. Y. Davis 2003,88 ). In a globalized prison industrial complex, prison is a source of "cheap labor" for private enterprises which thus avoid transport costs associated with the global south (Browne 2007; Thompson 2012, 40 ; Sudbury 2014). In US federal and state detention centers, hourly wages vary between 0.12 and 1.15 USD, whereas government prisons technically 
comply to minimum wage norms but retain most of detainees' salaries (Thompson 2012). Cheap labor is mainly achieved by poor Black people, who are overrepresented in private and governmental prisons: scholars and activists thus argue that prison labor is a $13^{\text {th }}$ Amendment-approved form of slavery in continuity with anti-Black racism (Browne 2007; Goodwin 2019). Penal plantation labor and prison farm labor are especially discussed in relation to slavery and systemic racism (Armstrong 2011 ; Isaacs 2016). Moreover, Halladay (2018, p. 963) frames unpaid or barely paid prison labor as part of an "intergenerational cycle of subjugation" which disproportionately affects incarcerated people of color who, upon exiting prison, are indebted and have no savings, predisposing them and their children to (re)incarceration.

[11] Although according to preconceived notions the United States are the only culprits, Québec and Canada also engaged in enslavement and indenture of Black and Indigenous people and have an ongoing history of colonialism, systemic racism, and forced labor (Maynard 2017). Forced labor - framed as a means of reforming Indigenous people - has indeed been a key colonial strategy deployed in residential schools, reservations, and penitentiaries (Chartrand, 2019). Criminalization based on race remains in Canada, disproportionately targeting Black and Indigenous people (Maynard 2017). Thus an attorney specialized in correctional law also draws a parallel between slavery and forced labor in Canadian penitentiaries (Magloé Francis 2017). She argues that prison labor is framed as a rehabilitation program yet is tied to successfully complying with a mandatory correctional intervention plan, effectively rendering it forced labor. According to her, non-compliance has a direct impact on detention conditions, prison security level, and obtention of conditional release.

[12] History also helps understand labor in women's prisons as gendered exploitation. Buck (2004) argues that most women's labor could be construed as alienating and underpaid, even more so in prison. In prison, women's rehabilitation was historically achieved through domesticity training aiming to refeminize unruly women according to middle-class, white standards (A. Y. Davis 2003). Specialized penal training in household management was used at the Prison for Women in Canada from the 1950 s to the 1970s, although gender-specific jobs like laundering, sewing, knitting, and domestic service existed from the 1880s (Hannah-Moffat 2001). Historically, refeminization through domesticity produced skilled 
Black servants thus reinforcing racism and classism (A. Y. Davis 2003). This is reflected in stereotypical training and jobs offered to detained women more recently (Morash, Haarr, and Rucker 1994 ; Pollack 2009). Stereotypically feminine jobs are less likely to pay well once a woman is released, which can negatively impact her social reinsertion prospects (Morash, Haarr, and Rucker 1994 ; Pollack 2009).

\section{CRITICAL PERSPECTIVES ON STRIP SEARCHES}

[13] Officially, strip searches aim to guarantee a prison's safety by preventing contraband (McCulloch and George 2008 ; Wahidin 2016). In practice, the effectiveness of strip searches has been called into question: for example, between 2001 and 2002, 18889 strip searches were conducted in an Australian prison with a daily population of 200, yet only 1 item of contraband was found (McCulloch and George 2008).

[14] Beyond this discrepancy, strip searches are cause for concern as they may be experienced as sexual assault and in continuity with structural harms experienced within society at large (Arbour 1996; NIMMIWG 2019 ; Hutchison 2020). This is especially relevant for detained women who face sexual victimization at exceedingly high rates: $68 \%$ of federally sentenced Canadian women have experienced sexual violence prior to incarceration (Hutchison 2020) whereas in Quebec jails, thrice as many women as men have issues with correctional intervention due to prior sexual victimization (32\% against 11\%, Giroux and Frigon 2011). The structurallyimpeded ability to consent is fundamental: even in the absence of physical force and even when conducted by women, strip searches in prison may be experienced as coercive given the repressive environment in which they occur (McCulloch and George 2008). Strip searches would be socially understood as sexual assault if the person conducting them was not wearing a uniform (George 1993). Through qualitative interviews with 5 women, Hutchison $(2020,166)$ indeed found that "women's experiences of being strip searched are consistent with experiences of being sexual assaulted" and resulting trauma. The power imbalance and inability to refuse to be strip searched without risking further punishment were key to this experience, which occurred hundreds of times over women's incarceration without getting easier to bear (Hutchison 2020).

[15] Strip searches can also be used by correctional officers as pretexts to commit sexual assaults (A. Y. Davis 2003; Hannah-Moffat 2001 ; Psutka and Sheehy 2016). Strip searches are humiliating - especially when 
menstruating - as well as isolating and dehumanizing (American Civil Liberties Union and Period Equity n.d. ; Arbour 1996 ; Hutchison 2019 ; McCulloch and George 2008 ; Psutka and Sheehy 2016 ; Smith 2009 ; Goldblatt and Steelet 2019). Strip searches experienced as sexual assault may also amplify issues linked to mental health and substance abuse and result in women being cut off from their families in an effort to avoid the trauma of being strip searched (McCulloch and George 2008 ; Goldblatt and Steelet 2019).

[15] Strip searches experienced as sexual assault also have racial, colonial, and cultural implications. Indeed, sexual violence was used to further subjugate enslaved Black women and deployed as a colonial tool targeting Indigenous women, which has repercussions to this day (A. Y. Davis 2003; McCulloch and George 2008). Black women remain construed as hypersexual, deviant Jezebels, a trope which "historically served the purpose of absolving white, male sexual violence against Black women" and to discredit reports of sexual victimization (A. Y. Davis 2003). Similarly, "negative associations of Indigenous women's sexuality - stemming from their colonial depiction as sexually depraved 'squaws' - has been used to justify sexual violence toward Indigenous women" (Maynard 2017, 160). The NIMMIWG (2019, p. 637) thus reports :

Almost all incarcerated Indigenous women have a history of sexual abuse, yet they are continually subjected to strip-searches. [...] In most instances, incarcerated Indigenous women are completely naked during the strip-search. As Commissioners heard, strip-searches are extremely traumatizing for many Indigenous women.

[16] Strip searches also have religious and cultural implications for instance in cases where a Muslim woman must remove her hijab (McCulloch and George 2008).

[17] These gendered and racial consequences lead incarcerated women and scholars to conclude that strip searches in prison constitute stateapproved sexual violence against women. Hutchison (2020) further argues that these sexual violences are inflicted by the state as they are practiced in state institutions and by its representatives. Indeed, strip searches may be used to control, humiliate, break, or punish incarcerated women (A. Y. Davis 2003 ; George 1993 ; Hutchison 2019; McCulloch and George 2008 ; Psutka and Sheehy 2016 ; Wahidin 2016). In allowing strip searches to occur, governments fail in their duties to protect the most 
vulnerable (Arbour 1996 ; A. Y. Davis 2003 ; George 1993 ; McCulloch and George 2008 ; NIMMIWG 2019).

[18] In the following sections, I add to these critical perspectives on prison labor and strip searches by analyzing correctional law in Quebec from an abolitionist perspective and considering its everyday implications for incarcerated women and their bodies.

\section{METHODOLOGY}

[19] The following analysis of prison labor and strip searches in the LSCQ stems from socio-legal methodology, meaning that "law is not viewed as an autonomous force to which society is subjected, but rather shapes and is shaped by broader social, political and economic logics, contexts and relations" (O'Donovan 2016). As opposed to doctrinal methodology which criticizes law through internal criteria such as clarity, socio-legal methodology relies on external criteria such as law's functioning in reality, effectiveness, and consequences, and may consider broader social solutions to issues with law (O'Donovan 2016). Socio-legal methodology may question law's functioning "in action" as opposed to "in books" (Pound 1910, title; O'Donovan 2016). This methodology also challenges assumptions about law's neutrality, namely through feminist legal methods (O'Donovan 2016). This paper specifically analyzes the LSCQ through the feminist socio-legal method of "asking the woman question" to "identify the gender implications of rules and practices which might otherwise appear to be neutral or objective" (Bartlett 1990, 837). This method consists in asking "how the law fails to take into account the experiences and values that seem more typical of women than of men, for whatever reason, or how existing legal standards and concepts might disadvantage women" to shed light on and correct male-centric features of law (Bartlett 1990, 837). Feminist legal theories and methods must beware of essentialism in assuming a homogenous experience of womanhood across social categories such as race, class, and sexuality (Harris 1990). Bartlett (1990) thus argues the woman question can become the question of the excluded to consider intersecting forms of oppression.

[20] I started analyzing the LSCQ as a term project for a graduate seminar on penal policy. In reading the report and political debates leading up to the adoption of this law (Corbo 2001 ; Assemblée nationale du Québec 
$2002 b$; 2002c ; 2002a), I noticed that women were discussed as potential victims especially of domestic violence, but never as incarcerated individuals. This prompted me to ask the woman question: "In what ways does the LSCQ account for incarcerated women?" Upon reading the LSCQ, I found that only one of 211 articles mentions women. This is to specify that in-prison programs and services such as leisure and labor should be adapted to women's and Indigenous detainees' needs (para. 21). Five years after the LSCQ was adopted, women were also mentioned in implementing regulation concerning body searches (Règ/ement d'application de la Loi sur le système correctionnel du Québec, hereafter r.1, 2007, paras. 20-23).

[21] Women incarcerated in Quebec jails are thus assumed to have specific needs in two areas of everyday life pertaining to what they do with, how they take care of, and how their bodies are treated during their stay. I came to explore labor and strip searches in prison with a focus on the body as punishment is experienced in women's bodies rather than through a solely psychological pain (Chamberlen 2016). And "rather than viewing women's bodies solely as gendered", this work "recognize[s] that gender is always racialized and classed" (Sudbury 2014, xv). In keeping with abolitionist concerns around harms perpetuated in prison, my analysis looks beyond that which is written in law to ask:

- How does the LSCQ frame prison labor and strip searches?

- How is it applied?

- What are potential gendered, racial, and class implications of this law considering women's bodies and everyday experiences?

- How can these be resolved?

[22] To answer these questions, I synthesize sections of the LSCQ and its regulation pertaining to both themes. I contrast this law in books with existing accounts of prison labor and strip searches in action in Quebec, using government reports, legal decisions, and local denounciations reported in media. As this yielded limited information, I further reflect on everyday implications of this legal framing for women and their bodies by weaving together findings and arguments drawn from local and international scholarship and reports. Relying on sources outside of Quebec is justified from an abolitionist perspective, as prison systems are 
"simultaneously local and global", meaning there are particularities as well as commonalities in light of transnational processes such as globalized capitalism, neoliberalism, and colonialism (Sudbury 2014, xii). This may also help draw connections between correctional law in Quebec can also form the basis for future work critiquing correctional law. I also fill in gaps by citing some testimonies from incarcerated individuals as reported in media.

\section{CORRECTIONAL LAW ON LABOR}

\section{WORK \& WAGES IN QUEBEC JAILS}

[23] The LSCQ frames labor in Quebec jails and specifies how and where prison wages go, which is connected to activities, services, and commissary. In each jail, the Activities Program for Offenders must provide paid or unpaid labor opportunities (para. 76) and is financed through its own Social Reinsertion Support Fund. This Fund is generated by retaining $10 \%$ of every detained person's wages as well as through profits obtained through the Activities Program (Règlement sur les programmes d'activités pour les personnes contrevenantes 2007, hereafter r.3, para. 15; LSCQ, para. 75), namely commissary sales. The Activities Program thus provides and manages labor, while its Fund relies on prison labor and detainees' commissary purchases to finance other social reinsertion activities.

Table 1. Quebec jail wages (CAD)

\begin{tabular}{|l|l|}
\hline Hourly Wage and Deductions & Calculations (CAD/hour) \\
\hline Provincial minimum wage & 12.50 \\
\hline Prison labor base wage & $12.50 \times 35 \%=4.38$ \\
\hline Deduction for Fund & $4.38-(4.38 \times 10 \%)=3.94$ \\
\hline $\begin{array}{l}\text { Commissary allowance (immediately available prison } \\
\text { wage) }\end{array}$ & $3.94 \div 2=1.97$ \\
\hline Trust account (prison wage available upon release) & $3.94 \div 2=1.97$ \\
\hline Percentage of minimum wage available to detainees & $1.97 \div 12.50=\mathbf{1 5 . 7 5 \%}$ \\
\hline
\end{tabular}

Based on Règlement sur les normes du travail (para. 3) and r.3 (para. 11, 15-16).

[24] Table 1 presents wages as established in the LSCQ, its implementing regulation, and regulation on labor standards. Detained people's hourly salary was set to 35\% of minimum wage in 2018 (r.3, para. 11). As of May 2020, minimum wage is 12.50 CAD/hour in Quebec (Règlement sur les 
normes du travail 1981, para. 3), which means that detained people earn a base wage of $4.38 \mathrm{CAD} /$ hour. An initial deduction of $10 \%$ goes to the Fund (r.3, para. 15). Detained people receive $50 \%$ of their remaining wages as an allowance for the commissary, so 1.97 CAD/hour (r.3, para. 16). The jail director places the remaining $1.97 \mathrm{CAD} /$ hour into a trust account until the person is released (r.3, para.16). Thus, for each hour of labor, detained people immediately have access to less than $16 \%$ of minimum wage and will eventually have access to another $16 \%$ upon release.

[25] Table 2. Average Wages in Quebec jails for Women (CAD)

\begin{tabular}{|l|l|l|l|l|l|l}
\hline $\begin{array}{l}\text { Paid jobs in } \\
\text { women's } \\
\text { prisons }\end{array}$ & $\begin{array}{l}\text { Yearly } \\
\text { hours of } \\
\text { labor }\end{array}$ & $\begin{array}{l}\text { Yearly } \\
\text { hours } \\
\text { labor/job }\end{array}$ & $\begin{array}{l}\text { Weekly } \\
\text { hours } \\
\text { labor/job }\end{array}$ & $\begin{array}{l}\text { Weekly } \\
\text { wages/job }\end{array}$ & $\begin{array}{l}\text { Weekly } \\
\text { available } \\
\text { wages/job }\end{array}$ & $\begin{array}{l}\text { Monthly } \\
\text { available } \\
\text { wages/job }\end{array}$ \\
\hline 128 & $109417 \mathrm{~h}$ & $854.8 \mathrm{~h}$ & $16.4 \mathrm{~h}$ & 64.62 CAD & $32.31 \mathrm{CAD}$ & $129.23 \mathrm{CAD}$ \\
\hline
\end{tabular}

Based on Borgia (2016) and Table 1.

[26] As for law in action, the above legal framing of labor implies that women earn very little in jail. According to the last available data, there were a total of 128 paid jobs in Quebec jails for women (Borgia 2016). These jobs totaled 109,417 hours of labor (Borgia 2016). As illustrated in Table 2, this means that each job averaged 16.4 hours of labor per week. Thus, every week, the women who held jobs earned 65 CAD on average; half of this amount (32 CAD) was available to spend at the commissary. Women thus averaged $129 \mathrm{CAD} /$ month to cover overpriced commissary items such as better food and hygienic products, potentially impacting quality of life in jail.

\section{IMPLICATIONS: COST \& QUALITY OF LIFE}

[27] Beyond racial and gendered sociohistorical harms, poor framing of prison labor and wages within the LSCQ has everyday and bodily implications for women. Indeed, women's wages in prison strongly contrast with the cost of living resulting from prison commissary prices. This especially harms poor women by limiting access to essential menstrual products.

[28] The cost of life in Quebec jails is not made explicit: the LSCQ does not limit commissary profits and no information on Quebec jail commissary prices is publicly available, beyond the mention that commissary profits 
fund activities and programs. Cost of life is likely disproportionate to wages in Quebec jails as is the case in Canada and worldwide. Indeed, the cost of life in prison is specifically addressed in the federal Canadian system, which limits commissary profit margins to $10 \%$ (Government of Canada 2002). In 1981, Correctional Services Canada created a typical commissary basket to control prices for the most frequently bought items (Office of the Correctional Investigator 2006). In 1981, this cart averaged 8.49 CAD ; due to inflation, it costs 61.59 CAD today. Despite these safeguards, daily net wages available for commissary purchases, phone calls, and family visits were 1.95 CAD in 2016 (Office of the Correctional Investigator 2016). Federal detainees demanded their salaries be doubled because of excessively high commissary prices but their application for judicial review of compensation was dismissed (Guérin v. Canada 2018). In France, commissary prices are up to twice regular prices (Attia, Benda, and Cincinatis 2019). Mobilizations around incarcerated people's rights in the United States and Europe often relay outcry as to grossly inflated commissary prices such as 17 USD ramen soup and 18 USD tampon boxes (Graves 2018; Wheeling 2018 ; Attia, Benda, and Cincinatis 2019 ; Ban Public 2016 ; Dedieu and Meignan 2011).

[29] Hygiene products and food can be purchased at commissary and are tied to women's corporal practices and attempts to do health within Quebec jails (Chesnay 2016). Thus the cost of life in Quebec jails is important because incarcerated people are ineligible for welfare (Loi Sur l'aide Aux Personnes et Aux Familles 2005, para. 25) ; compensating meager commissary allowances to purchase necessary products is only possible if one's relatives or friends have financial means of contributing. However, when entering Quebec jails, women are less often employed and more often poor, single parents who benefit from welfare (Giroux and Frigon 2011). By extension, women are less likely to benefit from relatives with sufficient means to regularly fund their commissary allowance. Poor women of color, an overrepresented population, would thus have differential access to a comfortable quality of life in prison.

[30] Disproportional cost of life in prison is particularly relevant to people who menstruate. Local and international scholars have shed light on period poverty, humiliatingly insufficient sanitary product rations, and discuss these practices as discriminatory or as means of disciplining women and their bodies (de Graaf 2013 ; Smith 2009 ; Bostock 2020 ; Wahidin 2019 ; Shrestha, Kuikel, and Bhandari 2014 ; Goldblatt and 
Steelet 2019). The everyday implications of rations are cause for concern: menstruating people likely need to complete their provisions through commissary purchases. Whereas federal Canadian commissaries sell tampons and pads (Government of Canada 2002), access to menstrual products in Quebec jails remains unspecified. Lack of legal delineation of commissary profits can lead to excesses, such as the 18 USD tampon box mentioned above, the box of tampons costing two weeks of wages in a Colorado prison, or individual pads sold from 2.63 to 4.23 USD (American Civil Liberties Union and Period Equity n.d. ; Durkin 2017). Excesses are worrisome in light of the demographic profile of women held in Quebec jails: this population is likely to experience period poverty, an issue within the general Canadian population (Hill + Knowlton Strategies and Plan International Canada 2018).

[31] Lack of legal framing regarding the cost of life and access to menstrual products in prison is especially worrying because prison affects menstrual experiences and can lead to suboptimal or even dangerous solutions. Indeed, material needs may grow in prison: among 111 British women, $49 \%$ reported a change in their menstruations and $41 \%$ reported a higher menstrual flux over the course of their incarceration (Smith 2009). Menstruating in prison is experienced as particularly intrusive yet menses cannot be managed by habitual means, such as napping or taking an anti-inflammatory, due to prison regulations (Smith 2009). Half of 131 women detained in Kathmandu reported using fabric scraps rather than pads due to prices, economic constraints, and lack of pad availability (Shrestha, Kuikel, and Bhandari 2014); in a Californian prison, none had adequate access to menstrual products (Arutunyan 2017). Insufficient access to menstrual products can lead to alternatives posing health risks, such as use of newspaper, irritating fabric, or unwashed fabric due to lack of soap (Van Hout and Mhlanga-Gunda 2018). One French media reports incarcerated women's testimonies of using socks or fashioning makeshift menstrual cups by cutting the top of a plastic bottle then filing the edge against a windowsill (Attia, Benda, and Cincinatis 2019).

[32] If prison labor can be understood as a modern extension of slavery and refeminization practices, it can also be critiqued as engendering everyday bodily harms on women due to inadequate wages relative to commissary prices, especially of menstrual products. 


\section{CORRECTIONAL LAW ON STRIP SEARCHES}

\section{STRIP SEARCHES IN QUEBEC JAILS}

[33] Correctional law in Quebec determines how strip and other body searches should be conducted, by whom, and under which circumstances. Search types and conditions are determined through regulation (LSCQ, para. 193) and regulation affirms that all body searches must be conducted in such a way as to respect human dignity and to minimize intrusion (r. 1, para. 24). Body searches include the discreet search, in which a clothed person is searched through technological means such as a metal detector; the summary search, in which a clothed person is manually searched; the strip search, in which a naked person is visually searched; the body cavity search, in which a naked person is manually searched by a medical doctor in front of a witness; the radiography, which is conducted by a board-certified radiologist (r. 1, para. 19-23). Thus strip searches should involve no physical contact and are the most invasive type which can be conducted by correctional officers.

Table 3. Strip search characteristics and criteria in Quebec jails

\begin{tabular}{|l|l}
\hline Types & Routine or non-routine \\
\hline $\begin{array}{l}\text { Reasonable } \\
\text { grounds }\end{array}$ & $\begin{array}{l}\text { Necessary: believe weapon or proof of crime are hidden } \\
\text { Unnecessary: hostage or escape, post-riot, emergency measure, } \\
\text { forbidden object posing a serious threat }\end{array}$ \\
\hline Manner & $\begin{array}{l}\text { Visual examination of all bodily folds } \\
\text { Authorized by manager if non-routine, unless emergency }\end{array}$ \\
\hline Gender & Women search women, unless emergency \\
\hline
\end{tabular}

Based on r. 1 (para. 21-28).

[34] Table 3 synthesizes strip search characteristics and criteria as set in the LSCQ. The individual must facilitate the visual examination of their every bodily fold when strip searched (r.1, para. 21). Unless there is an emergency, a woman can only be subjected to a strip search by another woman (r.1, para. 20-21). A correctional officer may proceed to strip searches in routine circumstances, such as when a person enters or exits 
the prison, an institutional vehicle, the visiting sector, sectors where they may have access to forbidden objects, or cells where they were alone (r.1, para. 27). A correctional agent may also proceed to summary or strip searches if they have reasonable grounds for thinking a person possesses a forbidden object, proof of a criminal offence, and if the search is necessary to retrieve said item (r.1, para. 28). A correctional agent does not need reasonable grounds to conduct such searches in the following circumstances: apprehended escape or hostage taking; after a riot; if a situation may trigger an emergency measure; if a forbidden object is seriously threatening the prison's or someone's life or security (r.1, para. 28). Furthermore, non routine searches require the responsible manager's permission, unless there is an emergency (r.1, para. 28).

[35] As for law in action, women are not always strip searched according to this law. Members of the CASIFQ report that strip searches are not always conducted in private areas of the women's jail (Groguhé 2018). In the injunction request against this jail, four women declared they had been strip searched without intimacy and that other people saw or may have seen their genitals. One woman stated she once remained naked for a few minutes because the correctional agent did not allow her to get dressed (Lafrance et al. 2019). Further, the injunction request argues that the basic principle of strip searches per regulation 1 - respecting human dignity - is not always respected (Lafrance et al. 2019, para. 26). Indeed, one woman stated she had lost all dignity while being strip searched and four women declared they felt humiliated.

\section{IMPLICATIONS: DISCRETION \& DISCRIMINATION}

[36] Empirical findings highlight the importance of understanding how correctional officers enforce law on a daily basis, using their discretion (Haggerty and Bucerius 2020). I argue this focus on law in action is especially crucial concerning strip searches as these may be experienced as state-inflicted sexual assault. Illegal strip searches occur across Canada "in spite of strong legal rulings that condemn this practice": Psutka and Sheehy $(2016,241)$ identified 43 criminal and 7 tort cases citing Charter violations and spanning 15 years, emphasizing how these were merely the tip of an inaccessible iceberg. One participant in Hutchison's (2020) study witnessed a woman be physically stripped of her clothes by correctional officers, in breach of Canadian jurisprudence ( $R \vee$ Golden 2001, para. 101). 
[37] Wording of rules, situations to which rules apply, and organizational missions all leave space for discretion (Liebling, Price, and Shefer 2010). Thus correctional officers in Quebec jails have much discretion in conducting a practice experienced as sexual violence. Officers may conduct strip searches if they have reasonable grounds to believe this is necessary to avoid imminent danger; yet a reasonable grounds requirement is impractical for those who "perform the law in everyday life" (Haggerty and Bucerius 2020, 3). Legally, reasonable grounds means another person in the same context would similarly interpret the situation ( $\mathrm{v}$ V Phung 2013). But who is this imaginary, presumably neutral outsider? From a feminist legal theory standpoint, in this context the reasonable grounds criterion is likely male-centric: the imaginary outsider is likely assumed to never have been strip searched nor sexually assaulted! Officers also have discretion as they do not require reasonable grounds to conduct strip searches as a matter of routine, despite routine strip searches being especially problematic for women (A. Y. Davis 2003; McCulloch and George 2008). The following remain unspecified, further allowing for discretion: the nature of emergencies in which men may search women; the nature of emergencies allowing correctional officers to conduct searches without supervisor authorization; the procedure to follow if someone refuses to be searched. This is problematic as women live in "fear of being punished for resisting being strip searched", which amplifies power imbalances and the violence of strip searches (Hutchison 2020, 167).

[38] Beyond the deployment of sexually violent practices, I argue that discretion in strip searching opens a breach for further, on-the-grounds racist practices adding another layer of everyday violence and harm. Indeed, correctional officers' discretion in strip searching may be a function of racial discrimination. Correctional officers are street-level bureaucrats, i.e. institution workers who exercise discretion in allocating benefits or sanctions (Lipsky 2010). Street-level bureaucrats often refer to stereotypes to distinguish their client population and properly exercise their discretionary power, especially within uncertain environments (Lipsky 2010). Thus correctional officers must heavily rely on discretion and pragmatically "pick [their] battles" as there are not enough hours in the day to enforce every single rule; their habitus, including work 
experience, shapes discretionary decision-making ( $n=131$, Haggerty and Bucerius 2020, 9).

[39] Correctional officers may also rely on stereotypes relating to race, gender, age, and criminal record to infer dangerousness (Wade-Olson 2019; Poole and Regoli 1980) and in turn, to determine a strip search is necessary. Forty years ago, one study found that Black and white men had similar rates of rule-breaking activity in prison, yet Black men were more likely to face official disciplinary action; in turn, prior sanctions increased the likelihood of future sanctions, thereby "amplifying the racial bias" ( $n=182$; Poole and Regoli 1980, 931). Recently, Olson (2016) found that correctional officers rely on racial stereotypes to shape discretion: indeed, Black people are more likely to be placed in solitary confinement $(n=11000)$. Further, white male prison staff have a higher preference for punishment than rehabilitation and "prisons with a high percentage of Black inmates utilize punishment at higher rates" than rehabilitation ( $n=734$ staff and 527 prisons; Wade-Olson 2019, 1397). Toman (2017, viii) also found "notable gender and racial/ethnic differences in official misconduct", pointing to differential rule enforcement: Black women were officially reported at higher rates compared to other women ( $n=169627$ people in 172 prisons). Thus the same Black, Indigenous, and other women of color who are overincarcerated may further punished and brutalized while in prison, in the form of strip searches motivated by racial bias.

[40] If the prison system is structured by gender and a function of racism, so too are everyday practices which can harm women's bodies. Considering the harms caused by strip searches in terms of sexual violence and the potential for racially motivated discretionary practices, it is crucial to reduce opportunities for correctional officer discretion in strip searching.

\section{DISCUSSION: ABOLITIONIST REFORMS}

[41] Despite official narratives around favoring social reinsertion, prison labor is rooted in systemic racism, colonialism, and sexism. Its framing in the LSCQ allows for inadequate wages relative to cost of living in prison; this limits access to menstrual products in prison, potentially leading to dangerous alternatives. As for strip searches, although they are presented as means to ensure institutional safety, they are experienced as unsafe 
and as state-inflicted sexual assault. The LSCQ allows strip searches to be conducted in a range of circumstances leaving much to correctional officers' discretion, thus creating space for discriminatory rule enforcement exposing Black, Indigenous, and other women of color to further everyday bodily harms.

[42] Within abolitionism, the ideal long-term, transformative response to prison labor and strip searches would be to decriminalize, decarcerate, and dismantle jails and prisons. There would be no fear of contraband affecting the safety of the institution if there were no such institution. It would also mean investing in communities and preventing criminalization by abolishing structures such as systemic racism, colonialism, sexism, and capitalism (A. Y. Davis 2003). Until such a time as we can collectively achieve these ideals, some pragmatic, short-term steps to minimizing bodily harms caused by prison labor and strip searches are discussed hereafter. Although I specifically address the LSCQ, I invite other scholars, practitioners, and advocates to extend this line of thinking to other correctional laws.

[43] In keeping with abolitionist tenets, regulation 3 could relatively easily be reformed by governmental decree in such a way as to reduce harms associated with prison labor. For now I would not recommend entirely eliminating prison labor, as this and other activities can benefit individuals by making time spent in prison less "unbearably long and painful", thus reducing the coerciveness of the institution (Marcoux Rouleau 2020, 3). Instead of reforming prison labor to solidify carceral logics, I see it as "means to make life in prison more livable and inmates more able to tackle life in society when release comes up" (Mathiesen 2014, 25). Work opportunities should be available but optional; incarcerated people should benefit from worker protections, be paid the same wages as nonincarcerated people, and have the option to decide how they manage their prison wages instead of systematically having half placed in a trust account. This would at least reduce the slavery connotation. Such a wage increase would inflate buying power without inflating commissary prices. Instead of retaining $10 \%$ of wages to fund activities and programs, these could be fully funded through commissary purchases. A range of menstrual products should be freely provided and unrationed in all prisons for women and be available on demand in prisons for men to account for transmasculine detainees' needs (see Bosquet 2020). In Quebec, the CASIFQ could mobilize to demand these changes, whereas 
alliances with worker unions could raise awareness as to wage issues and facilitate implementation. For example, the Industrial Workers of the World union has an Incarcerated Workers Organizing Committee (2016) which actively struggles against $13^{\text {th }}$ Amendment-approved enslavement of incarcerated individuals.

[44] As for strip searches, I initially thought to reiterate best practices put forth in Canadian jurisprudence and international guidelines: for example favoring discreet and summary searches, eliminating routine strip searches, ensuring incarcerated people are never fully naked by allowing items to be removed then put back on (per United Nations 2015, para. 52.1; R v Golden 2001, para. 101; United Nations 2010, para. 20). Correctional officers who do not respect the rules, for instance by removing clothes from the person or by strip searching someone of another gender, could also be sanctioned. However, I conclude that such reforms are insufficient: they do not reduce the systemic harms of incarceration nor do they address the inherent sexual violence of strip searches. They do not limit reliance on punitive logics: the safety of the institution, rather than that of individuals held therein, and punishment of individuals who break rules continue to be prioritized within these reforms. Further, sanctioning correctional officers diverts attention from institutional and state responsibility in relying on punitive logics in the first place.

[45] The abolitionist approach is to recognize that there is simply no way to conduct strip searches humanely and with minimal intrusiveness (per $r$. 1, para. 24). If strip searches are experienced as state-inflicted sexual assault, they should immediately be abolished by reforming regulation 1 . Indeed, as Hutchison $(2020,172)$ concludes :

\section{Until strip searching is abolished as a practice, women in prison will continue to be sexually assaulted by the state. While the Bangkok Rules provide a starting point for reducing the harms to women through strip searching, they do not eliminate the harms. Thus, the abolition of the use of strip searching in women's prisons is ne- cessary.}

[46] Not only that, but it is hypocritical for states and governments to incarcerate some people for committing sexual assaults while simultaneously inflicting this form of violence daily. The urgent need to abolish strip searches could be made clearer if the criterion to conduct these were rephrased in the following tangible terms limiting discretion : 
Is the potential danger to staff and detained people greater than the psychological, physical, and structural harms caused by a strip search? Is sexually assaulting someone justifiable considering the current circumstances and the danger a correctional officer is attempting to prevent?

[47] The answer should always be a resounding no! A greater diversity within \#MeToo mobilizations could help sensitize states, administrators, and correctional officers. Indeed, if lawmakers and prison administrators show themselves remiss to abolishing strip searches, perhaps correctional officers can be encouraged to exercise discretion in a forward-looking manner as is their wont (Haggerty and Bucerius 2020) and simply refuse to engage in this violent practice.

\section{Références bibliographiques}

American Civil Liberties Union, and Period Equity. n.d. "The Unequal Price of Periods: Menstrual Equity in the United States." Accessed May 20, 2020. https://www.aclu.org/sites/default/files/field_document/111219-sjperiodequity.pdf.

Arbour, Louise. 1996. Commission d'enquête sur certains événements survenus à la Prison des femmes de Kingston. Toronto: La Commission.

Armstrong, Andrea C. 2011. "Slavery Revisited in Penal Plantation Labor." Seattle University Law Review 35: 869.

Arutunyan, Inessa. 2017. "The Progressive Jail: An Exploration of Carceral Living Conditions and Employment/Educational Life Plans." Ph.D. diss., San Jose State University. https://search.proquest.com/docview/ 1929228429 ? accountid=12543.

Assemblée nationale du Québec. 2002a. "Journal Des Débats de La Commission Des Institutions: Consultations Particulières Sur Le Projet de Loi No 89 et Étude Détaillée Du Projet de Loi No 89 (36e Législature, 2e Session, Vol. 37, No 81)." mai 2002. http://www.assnat.qc.ca/fr/travauxparlementaires/commissions/ci-36-2/journal-debats/Cl-020530.html.

- - 2002b. "Journal Des Débats de l'Assemblée Nationale (36e Législature, 2e Session, Vol.37, No 112)." juin 2002. http:// www.assnat.qc.ca/fr/travaux-parlementaires/assemblee-nationale/36-2/ journal-debats/20020607/9665.html\#_Toc11482313. 
- - . 2002c. "Journal Des Débats de l'Assemblée Nationale (36e Législature, 2e Session, Vol.37, No 113)." juin 2002. http:// www.assnat.qc.ca/fr/travaux-parlementaires/assemblee-nationale/36-2/ journal-debats/20020611/9667.html\#_Toc11669031.

Attia, Myriam, Emma Benda, and Johana Cincinatis. 2019. "Précarité menstruelle : en prison, des femmes fabriquent des cups avec des bouteilles en plastique." L'Obs, March 19, 2019. https:// www.nouvelobs.com/nos-vies-intimes/20190319.OBS10781/precaritemenstruelle-en-prison-les-femmes-fabriquent-des-cups-avec-desbouteilles-en-plastique.html.

Ban Public. 2016. "Guide Du Prisonnier: Les Cantines." Ban Public, June 2016. http://prison.eu.org/spip.php?article359.

Bartlett, Katharine T. 1990. "Feminist Legal Methods." Harvard Law Review 103 (4): 829-88.

Borgia, S. 2016. "Fonds de soutien à la réinsertion sociale des établissements de détention, Fonds central de soutien à la réinsertion sociale, Comité consultatif du ministre: Rapport d'activités 2016." https:// www.securitepublique.gouv.qc.ca/fileadmin/Documents/ services_correctionnels/fonds_reinsertion_sociale/ rapport_activites_FCSRS_2016.pdf.

Bosquet, S. 2020. "Précarité menstruelle en prison: à quand la gratuité?" Club de Mediapart, March 12, 2020. https://blogs.mediapart.fr/ observatoire-international-des-prisons-section-francaise/blog/120320/ precarite-menstruelle-en-prison-quand-la-gratuite.

Bostock, Jessica. 2020. "Period Poverty in Prison: An Intersectional Commentary on the Lived Experiences of Incarcerated Women in US Prison Facilities." Routes: The Journal for Student Geographers 1 (1): 2-11.

Browne, Jaron. 2007. "Rooted in Slavery: Prison Labor Exploitation." Race, Poverty \& the Environment 14 (1): 42-44.

Buck, Marilyn. 2004. "Women in Prison and Work." Feminist Studies 30 (2): 451-55. https://doi.org/10.2307/20458974. 
Chamberlen, Anastasia. 2016. “Embodying Prison Pain: Women's Experiences of Self-Injury in Prison and the Emotions of Punishment." Theoretical Criminology 20 (2): 205-19. https://doi.org/ $10.1177 / 1362480615595283$.

Chartrand, Vicki. 2019. "Unsettled Times: Indigenous Incarceration and the Links between Colonialism and the Penitentiary in Canada." Canadian Journal of Criminology and Criminal Justice 61 (3): 67-89. https://doi.org/ 10.3138/cjccj.2018-0029.

Chéné, Bernard, and Eugénie Chouinard. 2018. "Profil Des Femmes Confiées Aux Services Correctionnels En 2015-2016." Québec: Direction générale des services correctionnels, ministère de la Sécurité publique.

Chesnay, Catherine Thérèse. 2016. “Doing Health, Undoing Prison: A Study with Women Who Have Experienced Incarceration in a Provincial Prison." Thesis, Université d'Ottawa / University of Ottawa. https://doi.org/ 10.20381/ruor-5980.

Corbo, Claude. 2001. “Pour Rendre plus Sécuritaire Un Risque Nécessaire: Rapport de l'examen, Effectué à La Demande Du Ministre de La Sécurité Publique Du Québec, Du Processus Décisionnel et Des Modalités d'encadrement Appliqués Lors de l'élargissement Des Personnes Contrevenantes." Montréal: Ministère de la sécurité publique.

Davis, Andrew P, and Michael Gibson-Light. 2020. "Difference and Punishment: Ethno-Political Exclusion, Colonial Institutional Legacies, and Incarceration." Punishment \& Society 22 (1): 3-27. https://doi.org/ 10.1177/1462474518816643.

Davis, Angela Y. 2003. Are Prisons Obsolete? Open Media Book. New York: Seven Stories Press.

Davis, Angela Y., and Cassandra Shaylor. 2001. "Race, Gender, and the Prison Industrial Complex: California and Beyond." Meridians 2 (1): 1-25.

Dedieu, F, and G Meignan. 2011. “Enquête Sur Le Coût de La Vie En Prison - L'Express L'Expansion." L'Expression L'Expansion, February 22, 2011. https:// lexpansion.lexpress.fr/actualite-economique/enquete-sur-le-cout-de-lavie-en-prison_1385297.html. 
Durkin, Abigail. 2017. "Profitable Menstruation: How the Cost of Feminine Hygiene Products Is a Battle against Reproductive Justice Notes." Georgetown Journal of Gender and the Law 18 (1): 131-72.

Gartner, Rosemary, Cheryl Marie Webster, and Anthony N. Doob. 2009. "Trends in the Imprisonment of Women in Canada." Canadian Journal of Criminology and Criminal Justice 51 (2): 169-98.

George, Amanda. 1993. "Strip Searches: Sexual Assault by the State." Alternative LJ 18 (1): 31-33.

Giroux, Lise, and Sylvie Frigon. 2011. "Profil correctionnel 2007-2008: Les femmes confiées aux Services correctionnels." Québec: Ministère de la sécurité publique, Direction de la recherche des services correctionnels.

Goldblatt, Beth, and Linda Steelet. 2019. "Bloody Unfair: Inequality Related to Menstruation - Considering the Role of Discrimination Law." Sydney Law Review 41 (3): 293-326.

Goodwin, Michele. 2019. "The Thirteenth Amendment: Modern Slavery, Capitalism, and Mass Incarceration." CORNELL LAW REVIEW 104: 899-990.

Government of Canada, Correctional Service of Canada. 2002. "Inmate Owned Canteens," September 1, 2002. https://www.csc-scc.gc.ca/policyand-legislation/890-cd-eng.shtml.

Graaf, Kaitlyn de. 2013. “DISCIPLINING WOMEN/DISCIPLINING BODIES: EXPLORING HOW WOMEN NEGOTIATE HEALTH AND BODILY AESTHETIC IN THE CARCERAL CONTEXT." Master of Arts (MA) in Criminology, Ottawa, Canada: University of Ottawa.

Graves, A. 2018. “Claims about Prison Price-Gouging Decry \$17 Soup, \$18 Tampons." PolitiFact Florida, January 22, 2018. https://www.politifact.com/ florida/article/2018/jan/22/claims-about-prison-price-gouging-decry-17soup-18/.

Groguhé, Marissa. 2018. "Établissement Leclerc: la violence derrière les barreaux." La Presse, décembre 2018. https://www.lapresse.ca/actualites/ justice-et-faits-divers/201812/06/01-5206999-etablissement-leclerc-laviolence-derriere-les-barreaux.php. 
Guérin v. Canada (Attorney General). 2018 94. Federal Court.

Haggerty, Kevin D., and Sandra M. Bucerius. 2020. "Picking Battles: Correctional Officers, Rules, and Discretion in Prison." Criminology n/a (n/ a). https://doi.org/10.1111/1745-9125.12263.

Halladay, Josh. 2018. "The Thirteenth Amendment, Prison Labor Wages, and Interrupting the Intergenerational Cycle of Subjugation Comments." Seattle University Law Review 42: 937-64.

Hannah-Moffat, Kelly. 2001. Punishment in Disguise: Penal Governance and Federal Imprisonment of Women in Canada. University of Toronto Press. https://www.deslibris.ca/ID/418119.

Harris, Angela P. 1990. "Race and Essentialism in Feminist Legal Theory." Stanford Law Review 42 (3): 581-616.

Hill + Knowlton Strategies, and Plan International Canada. 2018. "A Canadian Gender Study: Period Stigma." Plan International Canada. https://plancanada.ca/file/downloads/Plan-International-Canada---ACanadian-Gender-Study---Period-Stigma-Report-2018.pdf.

Hutchison, Jessica. 2019. '"Bend Over and Spread Your Butt Cheeks': Access to Justice for Women Strip Searched in Prison." The Annual Review of Interdisciplinary Justice Research 8: 65-90.

- - . 2020. "'It's Sexual Assault. It's Barbaric': Strip Searching in Women's Prisons as State-Inflicted Sexual Assault." Affilia 35 (2): 160-76. https:// doi.org/10.1177/0886109919878274.

Incarcerated Workers Organizing Committee. 2016. "About." 2016. https:// incarceratedworkers.org/about.

Isaacs, Tatum. 2016. "Farmers behind Bars: A Critical Analysis of Prison Farm Labor in Kentucky and beyond Notes." Kentucky Journal of Equine, Agriculture, \& Natural Resources Law 9: 507-32.

Lafrance, Gisèle, Véronique De Levo, Fédération des femmes du Québec, Ligue des droits et libertés, and Centre des femmes de Laval. 2019. Demande Pour l'émission d'ordonnances Provisoires, Ordonnances d'injonction 
Interlocutoire et Ordonnances d'injonction Permanente. Terrebonne, Québec: [Obtained through private communication].

Liebling, Alison, David Price, and Guy Shefer. 2010. The Prison Officer. Routledge.

Ligue des droits et libertés. 2019. "Communiqué - Requête en injonction concernant les conditions de détention à la prison Leclerc." Press Release. Ligue des droits et libertés. January 31, 2019. https://liguedesdroits.ca/ communique-requete-injonction-prison-leclerc-procedure-acceleree/.

- - 2021. “Communiqué : Les femmes incarcérées au Leclerc et leurs allié-e-s tirent encore la sonnette d'alarme - 5 ans de trop, il est temps que ça change!" Press Release. Ligue des droits et libertés. March 8, 2021. https://liguedesdroits.ca/communique-8-mars-lettre-casifq-Idl-5-ans/.

Lipsky, Michael. 2010. Street-Level Bureaucracy: Dilemmas of the Individual in Public Services. New York: Russell Sage Foundation.

Loi Sur l'aide Aux Personnes et Aux Familles. 2005. RLRQ c A-13.1.1. http:// legisquebec.gouv.qc.ca/fr/showdoc/cs/a-13.1.1.

Loi sur le système correctionnel du Québec. 2002. RLRQ c S-40.1. http:// legisquebec.gouv.qc.ca/fr/ShowDoc/cs/S-40.1.

Magloé Francis, Rita. 2017. "Le Semi-Esclavage Institutionnalisé." Revue À Bâbord !, March 2017. https://www.ababord.org/Le-semi-esclavageinstitutionnalise.

Marcoux Rouleau, Alexis. 2020. "Rethinking Incarcerated Women's Leisure as Subjected to Coercive and Normative Prison Missions." Frontiers in Sports and Active Living 2 (588775): 1-8. https://doi.org/10.3389/fspor. 2020.588775.

Mathiesen, Thomas. 2014. The Politics of Abolition Revisited. Routledge. https://doi.org/10.4324/9781315777900.

Maynard, Robyn. 2017. Policing Black Lives: State Violence in Canada from Slavery to the Present. Fernwood Publishing. 
McCulloch, Jude, and Amanda George. 2008. "Naked Power: Strip Searching in Women's Prisons." In The Violence of Incarceration, 117-33. Routledge.

Morash, M., R.N. Haarr, and L. Rucker. 1994. "A Comparison of Programming for Women and Men in U.S. Prisons in the 1980s." Crime \& Delinquency 40 (2): 197-221.

National Inquiry into Missing and Murdered Indigenous Women and Girls. 2019. "Reclaiming Power and Place: The Final Report of the National Inquiry into Missing and Murdered Indigenous Women and Girls, Volume 1a." CP32-163/2-1-2019E-PDF. https://www.mmiwg-ffada.ca/final-report/.

No Prisons. n.d. "Abolition 101." No Prisons. Accessed February 15, 2021. https://www.noprisons.ca/abolition-101.

O'Donovan, Darren. 2016. "Socio-Legal Methodology: Conceptual Underpinnings, Justifications and Practical Pitfalls." In Legal Research Methods: Principles and Practicalities, edited by Laura Cahillane and Jennifer Schweppe, 107-29. Dublin: Clarus Press.

Office of the Correctional Investigator. 2006. "Annual Report of the Office of the Correctional Investigator 2005-2006." PS100-2006E-PDF. https:// www.oci-bec.gc.ca/cnt/rpt/annrpt/annrpt20052006-eng.aspx.

- - . 2016. "Annual Report of the Office of the Correctional Investigator 2015-2016." PS100E-PDF.

Olson, Jeremiah C. 2016. "Race and Punishment in American Prisons." Journal of Public Administration Research and Theory 26 (4): 758-68. https:// doi.org/10.1093/jopart/muw026.

Pollack, Shoshana. 2009. "'You Can't Have It Both Ways': Punishment and Treatment of Imprisoned Women." Journal of Progressive Human Services 20 (2): 112-28. https://doi.org/10.1080/10428230903306344.

Poole, Eric D., and Robert M. Regoli. 1980. "Race, Institutional Rule Breaking, and Disciplinary Response: A Study of Discretionary Decision 
Making in Prison." Law \& Society Review 14 (4): 931-46. https://doi.org/ $10.2307 / 3053215$.

Pound, Roscoe. 1910. "Law in Books and Law in Action." American Law Review 44: 12-36.

Protecteur du citoyen. 2017. "Rapport Annuel d'activités 2016-2017." 47. Assemblée nationale du Québec. http://publications.virtualpaper.com/ uploads/protecteur_citoyen/rapport_annuel_2017/2017-09-12/fr/ rapport_annuel_2017.pdf.

- - 2019. "Rapport annuel d'activités 2018-2019 du Protecteur du citoyen." 49.

Psutka, Michelle, and Elizabeth Sheehy. 2016. "Strip-Searching of Women in Canada: Wrongs and Rights." La Revue Du Barreau Canadien 94: 241-79.

R. v. Golden. 2001, [2001] 3 SCR 679. Supreme Court of Canada.

R v Phung. 2013 63. ABCA.

Règlement d'application de la Loi sur le système correctionnel du Québec. 2007. RLRQ c S-40.1, r. 1. http://legisquebec.gouv.qc.ca/fr/ShowDoc/cr/ S-40.1,\%20r.\%201\%20/.

Règlement sur les normes du travail. 1981. RLRQ c N-1.1, r. 3. http:// legisquebec.gouv.qc.ca/fr/ShowDoc/cr/N-1.1,\%20r.\%203\%20/.

Règlement sur les programmes d'activités pour les personnes contrevenantes. 2007. RLRQ c S-40.1, r. 3. http://legisquebec.gouv.qc.ca/ $\mathrm{fr} /$ ShowDoc/cr/S-40.1,\%20r.\%203\%20/.

Ross, Robert R., and Elizabeth Fabiano. 1986. Female Offenders: Correctional Afterthoughts. McFarlane.

Russell, Emma, and Bree Carlton. 2013. "Pathways, Race and Gender Responsive Reform: Through an Abolitionist Lens." Theoretical Criminology 17 (4): 474-92. https://doi.org/10.1177/1362480613497777.

Shrestha, Sanu, Sushma Kuikel, and Saroj Bhandari. 2014. "Menstrual Hygiene among Prison Women in Kathmandu." International Journal of Health Sciences, no. 10: 8. 
Smith, Catrin. 2009. "A PERIOD IN CUSTODY: MENSTRUATION AND THE IMPRISONED BODY." Internet Journal of Criminology, 1-22.

Sudbury, Julia. 2009. "Maroon Abolitionists." Meridians 9 (1): 1-29. https:// doi.org/10.2979/MER.2008.9.1.1.

-_- 2014. Global Lockdown : Race, Gender, and the Prison-Industrial Complex. Routledge. https://doi.org/10.4324/9781315810812.

Thompson, Heather Ann. 2012. "The Prison Industrial Complex: A Growth Industry in a Shrinking Economy." New Labor Forum 21 (3): 39-47. https:// doi.org/10.4179/NLF.213.0000006.

Toman, Elisa L. 2017. "Female Incarceration and Prison Social Order: An Examination of Gender Differences in Prison Misconduct and In-Prison Punishments." Ph.D. diss., University of South Florida. https:// scholarcommons.usf.edu/etd/6966.

United Nations. 2010. United Nations Rules for the Treatment of Women Prisoners and Non-Custodial Measures for Women Offenders (the Bangkok Rules). Vol. Resolution 65/229. https://cdn.penalreform.org/wp-content/uploads/ 2016/07/BangkokRules-Updated-2016-with-renumbering-SMR.pdf.

- - - 2015. The United Nations Standard Minimum Rules for the Treatment of Prisoners (Nelson Mandela Rules).

Van Hout, Marie Claire, and Rosemary Mhlanga-Gunda. 2018. "Contemporary Women Prisoners Health Experiences, Unique Prison Health Care Needs and Health Care Outcomes in Sub Saharan Africa: A Scoping Review of Extant Literature." BMC International Health and Human Rights 18 (1): 31. https://doi.org/10.1186/s12914-018-0170-6.

Wade-Olson, Jeremiah. 2019. "Race, Staff, and Punishment: Representative Bureaucracy in American State Prisons." Administration \& Society 51 (9): 1397-1424. https://doi.org/10.1177/0095399716667156.

Wahidin, Azrini. 2016. Ex-Combatants, Gender and Peace in Northern Ireland: Women, Political Protest and the Prison Experience. Palgrave Studies in Compromise after Conflict. London: Palgrave Macmillan. 
- - - 2019. "Menstruation as a Weapon of War: The Politics of the Bleeding Body for Women on Political Protest at Armagh Prison, Northern Ireland." The Prison Journal 99 (1): 112-31. https://doi.org/ 10.1177/0032885518814730.

Walmsley, Roy. 2015. “World Female Imprisonment List, 3rd Ed." Institute for Criminal Policy Research. www.prisonstudies.org/sites/default/files/

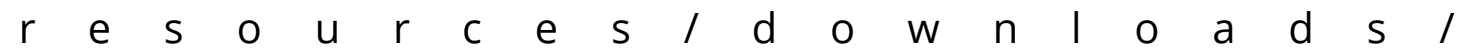
world_female_imprisonment_list_third_edition_0.pdf.

Wheeling, K. 2018. "Are Prison Commissaries Fair?" Pacific Standard, May 30, 2018. https://psmag.com/social-justice/are-prison-commissaries-fair. 